\title{
PENINGKATAN KUALITAS PEMBELAJARAN PAI MELALUI METODE CARD SORT PADA SISWA KELAS III SD NEGERI 3 BATURAGUNG KECAMATAN GUBUG KABUPATEN GROBOGAN
}

\author{
Baidlowi \\ SDN 3 Baturagung Gubug Grobogan \\ baidlowi31@gmail.com
}

\begin{abstract}
Before this classroom action research is implemented, the quality of learning at third grade islamic religion studies is low. This condition because the method of learning which teacher use is still conventional method, the students only sit down and listen to the teacher's explanation of material, without any direct experience. This classroom action research is show that there is any increase of teacher's skill, student's activities and student learning outcome in islamic religion studies. In the first cycle mean the percentage of teacher's skill is $70 \%$ with good category, increased at second cycle much as 95\% with very good category. The percentage of student's activity at first cycle much as $47 \%$ with enough category dan increased in second cycle much as $76 \%$ with good category. Student learning outcome at first cycle reach 71,42\% (15 of 21 students achieve the KKM) in good category and increase at second cycle 28,58 to 100\%, while the indicator of success is $90 \%$ of students reaches KKM.
\end{abstract}

\begin{abstract}
ABSTRAK
Sebelum dilaksanakannya penelitian tindakan kelas ini, kualitas pembelajaran PAI pada siswa kelas III rendah. Kondisi ini disebabkan karena metode pembelajaran yang digunakan oleh guru masih konvensional, siswa hanya duduk dan mengamati penjelasan guru terhadap materi, tanpa ada pengalaman langsung. Metode card sort merupakan metode dalam pembelajaran untuk mengajarkan konsep, penggolongan sifat serta fakta tentang suatu objek atau informasi. Metode ini sangat menarik untuk diterapkan dalam pembelajaran PAI, sehingga siswa menjadi aktif dan termotivasi dalam kegiatan pembelajaran. Kondisi awal pretest menunjukkan hanya $42,85 \%$ siswa yang mencapai KKM dengan rata-rata kelas 63. Hasil penelitian tindakan kelas ini menunjukkan adanya peningkatan keterampilan guru, aktivitas belajar siswa dan hasil belajar siswa pada mata pelajaran PAI. Pada siklus I, rerata prosentase keterampilan guru 70\% dengan kategori baik, dan meningkat pada siklus II sebanyak 95\% dengan kategori sangat baik. Prosentase aktivitas siswa pada siklus I sebanyak 47\% dengan kategori cukup dan meningkat pada siklus II sebanyak $76 \%$ dengan kategori baik. Hasil belajar siswa pada siklus I mencapai 71,42\% (15 dari 21 siswa mencapai KKM) dalam kategori baik meningkat pada siklus II naik 28,58 \% menjadi 100\%, sedangkan indikator keberhasilannya adalah 90\% siswa mencapai KKM.
\end{abstract}

Kata kunci: Metode Card Sort, Kualitas Pembelajaran

\section{Jurnal Refleksi Edukatika}

Vol. 6 No. 2 Juni 2016 


\section{PENDAHULUAN}

Kondisi awal pembelajaran PAI di SD Negeri 3 Baturagung menunjukkan guru masih menggunakan metode konvensional yaitu metode ceramah yang hanya diselingi tanya jawab. Guru lebih banyak mendominasi kegiatan pembelajaran, sedangkan peserta didik hanya duduk dan memperhatikan penjelasan guru terhadap materi pembelajaran. Guru tidak menggunakan metode pembelajaran yang menarik siswa untuk aktif dalam kegiatan pembelajaran. Siswa juga lebih banyak terangsang untuk mengingat dan menghafal materi pelajaran sehingga materi pelajaran akan bertahan sebentar saja dalam ingatan mereka. Hal ini menyebabkan minat dan motivasi belajar siswa rendah sehingga berdampak pada hasil belajar PAI siswa yang rendah. Kondisi seperti ini perlu diperbaiki dengan menggunakan metode pembelajaran yang tepat agar dapat meningkatkan kualitas pembelajaran PAI salah satunya dengan menggunakan metode card sort.

Metode card sort adalah metode pembelajaran yang mengajak peserta didik agar mempunyai jiwa yang mandiri sehingga dapat meningkatkan kreativitas peserta didik untuk membuat inovasi dalam pembelajaran (Ismail, 2006). Metode ini merupakan metode pembelajaran melalui permainan sehingga dapat menarik minat siswa untuk belajar. Melalui permainan siswa akan berkembang dalam segi perkembangan berpikirnya maupun kemampuan mengontrol emosi serta melakukan sosialisasi dengan siswa lain dalam kelas, sehingga dapat digunakan untuk mengajarkan konsep, penggolongan sifat, fakta tentang suatu obyek atau mengulangi informasi.

Bertolak dari kekurangefektifan pembelajaran PAI di atas, untuk membantu siswa kelas III SD Negeri 3 Baturagung kecamatan Gubug agar menguasi materi dengan baik maka penulis merumuskan masalah perbaikan "Apakah metode card sort dapat meningkatkan kualitas pembelajaran PAI pada siswa kelas III SD Negeri 3 Baturagung Kecamatan Gubug?"

Penelitian ini bertujuan untuk Untuk meningkatkan kualitas pembelajaran PAI melalui metode card sort pada siswa kelas III SD Negeri 3 Baturagung Kecamatan Gubug.

Hasil penelitian ini dapat dapat memberikan manfaat bagi siswa, guru, dan sekolah. Manfaat bagi siswa yaitu siswa akan lebih bersemangat dan termotivasi dalam mengikuti proses pembelajaran PAI. Selain itu siswa akan berperan aktif dalam berpartisipasi dan berinteraksi dengan teman yang lain sehingga akan mendapatkan pengalaman belajar yang berkesan dan materi akan tersimpan dalam memori jangka panjang. Selain itu siswa akan mudah dalam mencapai tujuan pembelajaran yang ditetapkan oleh guru serta meningkatkan prestasi belajarnya, bagi guru yaitu guru dapat meningkatkan kualitas pembelajaran seperti pembelajaran yang menarik, tidak monoton, serta menyenangkan. Selain itu untuk mengembangkan kreativitas guru dalam pengembangan pembelajaran yang inovatif, dan bagi sekolah yaitu diharapkan dapat meningkatkan mutu pembelajaran di SD Negeri 3 Baturagung. Selain itu juga dapat memberikan pengalaman pada guru-guru di SD Negeri 3 Baturagung sehingga memperoleh pengetahuan dan pengalaman baru untuk menerapkan berbagai pendekatan serta inovasi yang dapat digunakan sebagai referensi dalam memberikan pengajaran.

\section{METODE PENELITIAN}

Penelitian ini merupakan penelitian tindakan kelas yang memiliki empat tahapan yang akan dilalui yaitu: perencanaan, tindakan, observasi, dan refleksi (Arikunto dkk., 2006). Keempat tahapan ini dilaksanakan dalam dua siklus, setiap tahapan siklus didasarkan atas masukan dari siklus sebelumnya. Peneliti menggunakan metode card sort pada setiap siklus. Penelitian ini dilakukan mulai tanggal 3 Agustus sampai dengan 31 Oktober 2015 di SD Negeri 3 Baturagung Kecamatan Gubug. 
Sebelum pelaksanaan tiap siklus, dilakukan observasi awal. Observasi tahap awal dimulai pada tanggal 25 Juli 2015. Subyek dalam penelitian ini adalah peserta didik kelas III SD SD Negeri 3 Baturagung Kecamatan Gubug Tahun Pelajaran 2015/2016 yang berjumlah 21 siswa dengan komposisi 8 siswa putra dan 13 siswa putri. Selain peserta didik, subyek lainnya yang juga ikut diteliti adalah guru PAI.

\section{Siklus I}

\section{a. Tahap Perencanaan}

Pada tahapan ini dilakukan rencana kegiatan dengan menyesuaikan model yang akan diterapkan sebagai berikut:

1) Menyusun Rencana Pelaksanaan Pembelajaran (RPP) sebagai acuan pelaksanaan proses pembelajaran dengan berdasar kurikulum yang berlaku. Penyusunan RPP ini juga disesuaikan dengan langkah-langkah pada metode pembelajaran yang diterapkan, dalam hal ini metode card sort.

2) Membuat alat bantu pembelajaran berupa kartu indeks.

3) Menyusun lembar observasi keterampilan guru dan aktivitas peserta didik

4) Menyusun tes akhir setiap siklus

b. Tahap Tindakan

Pada tahapan ini pelaksanaannya didasarkan rencana pembelajaran yang disusun sebelumnya dengan kegiatan sebagai berikut:

1) Melaksanakan pembelajaran di kelas III sebagai kelas yang telah ditetapkan sebelumnya dengan menggunakan metode pembelajaran yang diterapkan berdasar RPP yang telah dibuat peneliti bersama kolaborator.

2) Guru menyiapkan kartu berisi tentang materi pokok sesuai SK/KD mapel, jumlah kartu sama dengan jumlah peserta didik di kelas dan isi kartu terdiri dari kartu induk/topik utama dan kartu rincian).

3) Seluruh kartu diacak/dikocok agar campur.

4) Membagi kartu kepada peserta didik dan pastikan masing-masing memperoleh satu atau dua kartu.

5) Memerintah setiap peserta didik bergerak mencari kartu induknya dengan mencocokkan kepada kawan sekelasnya.

6) Setelah kartu induk beserta seluruh kartu rinciannya ketemu, meminta masing-masing membentuk kelompok dan menempel hasilnya di papan secara urut.

7) Melakukan koreksi bersama setelah semua kelompok menempelkan hasilnya.

8) Meminta salah satu penanggungjawab kelompok untuk menjelaskan hasil sortir kartunya, kemudian meminta komentar dari kelompok lainnya.

9) Memberi apresiasi setiap hasil kerja peserta didik.

10) Melakukan klarifikasi, penyimpulan dan tindak lanjut.

11) Melaksanakan tes akhir pembelajaran tiap siklus.

c. Observasi

Dalam kegiatan ini observer melaksanakan pengamatan, pencatatan, dan menginterpretasi terhadap berlangsungnya pembelajaran, pada guru dan peserta didik dengan sambil mengerjakan lembar observasi yang telah disediakan. Pada tahap ini pula ketelitian dan kecermatan dalam mencatat dan mengamati sangat diperlukan, apalagi bila terjadi suatu perubahan mendadak dalam pelaksanaan tindakan yang ditimbulkan akibat respon peserta didik yang dikenai tindakan.

Pada tahap ini, selain pengerjaan lembar observasi untuk membuktikan pengamatan yang dilaksanakan, perlu

\section{Jurnal Refleksi Edukatika}


bukti dokumentasi berupa pengambilan gambar jika diperlukan agar dalam penginterpretasian data dapat lebih jelas dan cermat.

d. Refleksi

Pada tahap ini data-data yang diperoleh dari tiap siklus dikumpulkan untuk dianalisis selanjutnya diadakan refleksi terhadap hasil analisis sehingga dapat diketahui ada tidaknya peningkatan hasil belajar sebelum tindakan dan sesudah tindakan. Hasil belajar inilah yang nantinya digunakan sebagai bahan pertimbangan pelaksanaan siklus berikutnya.

\section{Siklus II}

Siklus II merupakan perbaikan dari siklus I. Siklus II merupakan klimak dari penelitian tindakan kelas ini. Karena menurut perkiraan penulis, pada siklus II ini hasil belajar peserta didik sudah memenuhi target pembelajaran. Langkah-langkahnya sama dengan siklus sebelumnya yaitu:

a. Tahapannya tetap perencanaan, tindakan, pengamatan dan refleksi

b. Materi pelajaran berkelanjutan

c. Diharapkan efektivitas kerja peserta didik harus lebih tinggi dari pada siklus I

d. Di akhir kegiatan/siklus, peneliti memberikan evaluasi sesuai dengan pokok bahasan yang diberikan.

\section{HASIL DAN PEMBAHASAN}

Hasil penelitian tindakan kelas dengan menggunakan metode card sort pada pembelajaran PAI kelas III SD Negeri 3 Baturagung menunjukkan terjadi peningkatan hasil belajar siswa dari nilai kognitif pretes. Adapun hasil belajar siswa dalam mengerjakan soal pretest sebelum diadakannya penelitian tindakan kelas ini dapat dilihat pada tabel 1 berikut.

Tabel 1. Rekapitulasi Nilai Pretest PAI Siswa Kelas III SD Negeri 3 Baturagung

\begin{tabular}{|c|l|c|}
\hline No & \multicolumn{1}{|c|}{ Uraian } & Keterangan \\
\hline 1 & Nilai terendah & 47 \\
\hline 2 & Nilai tertinggi & 73 \\
\hline 3 & Nilai rata-rata kelas & 63 \\
\hline 4 & Jumlah peserta didik yang belum tuntas belajar & 12 \\
\hline 5 & Jumlah peserta didik yang tuntas belajar & 9 \\
\hline 6 & Prosentase ketuntasan klasikal & $42,85 \%$ \\
\hline
\end{tabular}

Dari data diatas menunjukkan hasil belajar PAI siswa kelas III belum maksimal. Permasalahan yang ditemukan terkait dengan keterampilan guru dalam mengajar PAI yaitu (1) kurang membangkitkan motivasi siswa untuk belajar; (2) tidak menggunakan metode pembelajaran yang menarik; (3) materi yang disampaikan susah dipahami; (4) kurang melibatkan siswa untuk aktif dalam pembelajaran; (5) tidak memberi apersepsi di awal pembelajaran.

Permasalahan dari siswa kelas III SD Negeri 3 Baturagung berhubungan dengan aktivitas siswa dalam pembelajaran yaitu, (1) siswa belum mencapai KKM yang ditetapkan yaitu $\geq 65(42,85 \%$, yaitu 12 dari 21 siswa belum mencapai KKM); (2) siswa kurang aktif dalam kegiatan pembelajaran; (3) sebagian siswa merasa jenuh dan bosan terhadap metode pembelajaran yang dilaksanakan.

Setelah dilakukan perbaikan pembelajaran pada siklus I dan II, maka terjadi peningkatan keterampilan mengajar guru. Hasil pengamatan tersebut dinyatakan pada diagram I berikut ini. 
Diagram 1 Peningkatan Keterampilan Mengajar Guru

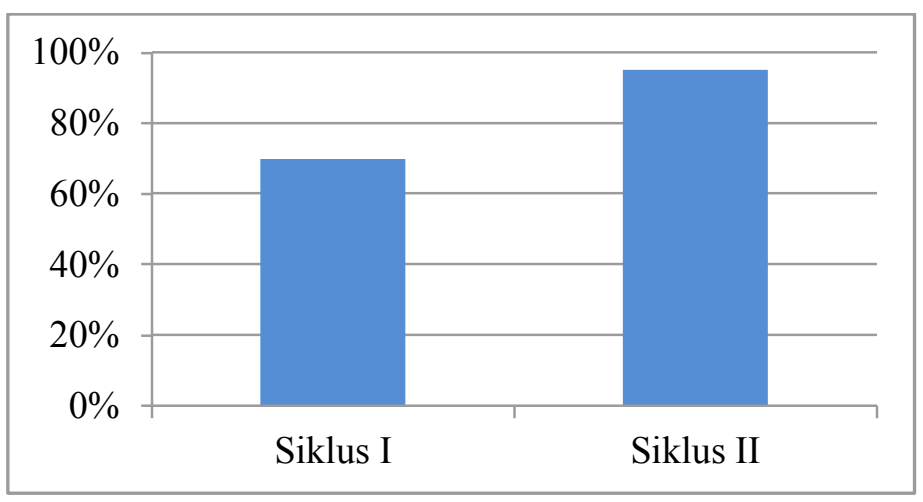

Berdasarkan diagram diatas dapat materi pembelajaran yang akan dipelajari. Pada disimpulkan bahwa terjadi peningkatan siklus II guru telah mampu melaksanakan 8 keterampilan guru sebesar $25 \%$ dari siklus I keterampilan mengajar guru dengan baik, yaitu 70\% dan meningkat pada siklus II menjadi sehingga peningkatan keterampilan mengajar 95\%. Pada siklus I guru telah mampu guru berdampak terhadap aktivitas belajar membangkitkan motivasi siswa sehingga siswa siswa. Adapun hasil pengamatan terhadap terlibat aktif dalam partisipasi pada aktivitas belajar siswa pada siklus I dan II pembelajaran, akan tetapi apersepsi yang dinyatakan dalam prosentase aktivitas belajar diberikan oleh guru terlalu cepat sehingga siswa siswa pada diagram II berikut ini.

belum mempunyai pandangan yang jelas terkait

\section{Diagram 2 Peningkatan Aktivitas Belajar Peserta Didik}

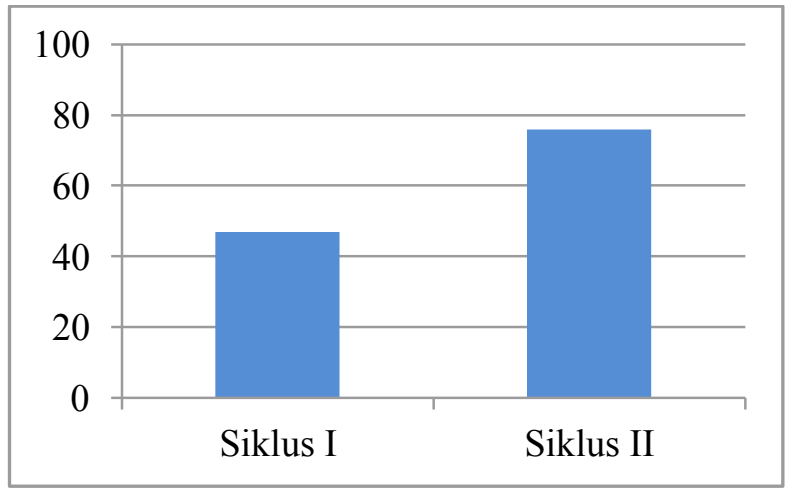

Berdasarkan diagram diatas dapat disimpulkan bahwa terjadi peningkatan aktivitas belajar siswa sebesar 29\% dari siklus I sebanyak $47 \%$ meningkat menjadi $76 \%$ pada siklus II. Pada siklus I siswa mulai aktif bertanya dan menyampaikan pendapat, akan tetapi masih terdapat siswa yang diam. Pada siklus II terlihat semangat siswa yang tinggi dalam pembelajaran. Siswa juga telah mampu bekerjasama dengan kelompoknya. Adanya peningkatan keterampilan mengajar guru dan aktivitas belajar siswa menyebabkan peningkatan hasil belajar siswa yang terlihat pada diagram 3 berikut ini. 


\section{Diagram 3 Peningkatan Hasil Belajar Peserta Didik}

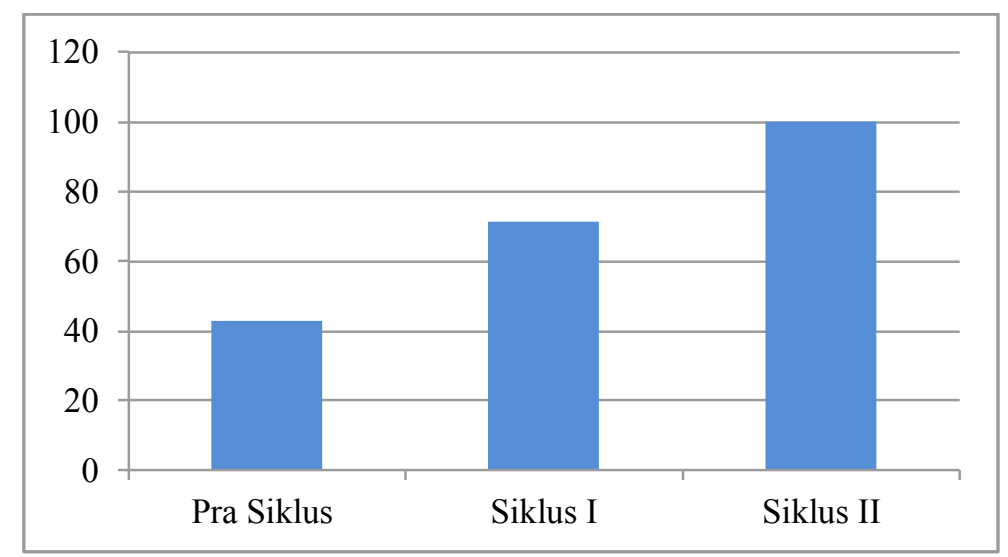

Terjadi peningkatan ketuntasan klasikal hasil belajar siswa sebesar $28,58 \%$ dari siklus I ke siklus II. Pada siklus I sebanyak 15 dari 21 siswa mencapai KKM dengan kategori baik, setelah diadakan perbaikan pada siklus II, seluruh siswa kelas III sebanyak 21 siswa telah mencapai KKM dengan kategori sangat baik.

Penelitian yang dilakukan oleh Siti Faizah memaparkan penggunaan metode card sort berpengaruh terhadap hasil belajar siswa. Dengan penerapan metode ini merangsang siswa untuk aktif dalam kegiatan pembelajaran. Siswa sangat antusias dan berlatih untuk berpikir secara kritis dan kreatif dalam kegiatan pembelajaran. Kegiatan pembelajaran melalui metode ini dilakukan secar berkelompok sehingga melatih kerjasama siswa. Guru juga dituntut untuk kreatif dalam menciptakan pembelajaran yang menyenangkan bagi siswa, sehingga pembelajaran yang diberikan oleh guru akan bermakna.

\section{SIMPULAN}

Berdasarkan hasil penelitian mengenai peningkatan kualitas pembelajaran PAI melalui metode card sort pada siswa kelas III SD Negeri 3 Baturagung Kecamatan Gubug Kabupaten Grobogan, peneliti dapat menarik kesimpulan sebagai berikut:

a. Adanya peningkatan keterampilan guru pada proses pembelajaran.

b. Adanya peningkatan aktivitas belajar siswa pada proses pembelajaran. c. Adanya peningkatan hasil belajar siswa yang diperoleh pada pembelajaran PAI.

Peneliti juga menyarankan bagi guru sebaiknya dapat menerapkan pembelajaran PAI melalui metode card sort karena dapat meningkatkan keterampilan guru dan aktivitas belajar siswa yang berpengaruh terhadap peningkatan hasil belajar siswa.

\section{DAFTAR PUSTAKA}

Anitah, Sri, dkk. 2009. Strategi Pembelajaran. Jakarta: Universitas Terbuka.

Arikunto, Suharsimi. 2002. Prosedur Penelitian Suatu Pendekatan Praktek. Jakarta: Rineka Cipta.

Arikunto, Suharsimi, dkk. 2006. Penelitian Tindakan Kelas. Jakarta: Bumi Aksara.

Arsyad, azhar. 2011. Media Pembelajaran. Jakarta : Rajawali press

Aqib, Zainal. 2009. Penelitian Tindakan Kelas.Bandung: Yrama widya

Azis, Sholeh Abdul dan Abdul Azis Madjid. Tarbiyah Wa Turuqu At-Tadris. Jus. 1. Makkah : Darul Ma'rif, tth. 
Daradjat, Zakiyah. 2006 Metodik Khusus Pengajaran Agama Islam, (Jakarta: Bumi Aksara.

Departemen Agama RI. 2006. Undang-undang dan Peraturan Pemerintah RI tentang Pendidikan, Jakarta: Direktorat Jendral Pendidikan Islam Departemen Agama RI.

Doyin, Mukh dan Wagiran. 2009. Bahasa Indonesia Pengantar Penulisan Karya Ilmiah.Semarang: UNNES PRESS.

Ismail, Andang. 2006 Education Games: Menjadi Cerdas dan Ceria dengan Permainan Edukatif, Yogyakarta: Pilar Media.

Ismail, SM. 2008. Strategi Pembelajaran Agama Islam Berbasis PAIKEM: Pembelajaran Aktif, Inovatif Kreatif, Efektif, dan Menyenangkan, Semarang: RASAIL Media Group, 2008.

Ramayulis. 2005. Metodologi Pengajaran Agama Islam, Jakarta: Kalam Mulia, 1990.
Rifa'i, Achmad, dan Chatarina Tri Anni. 2009. Psikologi Pendidikan. Semarang: Unnes Press.

Poerwanti, Endang, dkk. 2008. Asessmen Pembelajaran SD. Jakarta: Direktorat Jenderal Pendidikan Tinggi Departemen Pendidikan Nasional.

Syah, Muhibbin. 2000. Psikologi Pendidikan dengan Pendekatan Baru, Bandung: Remaja Rosdakarya.

Syaiful Bahri Djamarah dan Azwan Zain. 2002 Strategi Belajar Mengajar, Jakarta: Rineka Cipta.

Uno, Hamzah B. 2008. Model Pembelajaran: Menciptakan Proses Belajar Mengajar yang Kreatif dan Efektif, Jakarta: Bumi Aksara.

Usman, Moh. Uzer. 1998. Menjadi Guru Profesional, Bandung: Remaja Rosdakarya. 